African Crop Science Journal by African Crop Science Society is licensed under a Creative Commons Attribution 3.0 Uganda License. Based on a work at www.ajol.info/ and www.bioline.org.br/cs

DOI: https://dx.doi.org/10.4314/acsj.v28i1.23S

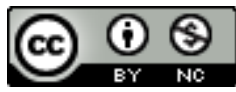

\title{
POTENTIAL FOR CROWN DIAMETER AS A PREDICTOR OF CANOPY COVER UNDER NATIONAL PARK CONDITIONS
}

\author{
S.T. ANGOMBE, R.N. SHIKANGALAH, E.G. KWEMBEYA ${ }^{1}$ and N. KANIME ${ }^{2}$
}

Department of Geography, History and Environmental Studies, University of Namibia, Private Bag 13301, Windhoek, Namibia

${ }^{1}$ Department of Biological Sciences, University of Namibia, Private Bag 13301, Windhoek, Namibia

${ }^{2}$ Ministry of Environment and Tourism, Private Bag 13306, Windhoek, Namibia

Corresponding author: sangombe@unam.na

\begin{abstract}
The global loss of biodiversity has led to relentless calls from conservationists to protect the environment and natural habitats. The objective of this study was to determine the effectiveness of crown diameter for prediction of canopy cover under national park conditions. The study was conducted in Etosha National Park, Namibia in 2015. Three tree species, namely Combretum imberbe, Colophospermum mopane and Terminalia prunioides were considered as representative members of the park species based on their relative population density. The study employed regression analysis to examine the nature of relationships between tree crown diameter (the dependent variable) and tree height, diameter at breast height (DBH) and distance from watering holes as independent variables. The regression coefficients for Combretum imberbe were not significant $(\mathrm{P}=0.116 ; \mathrm{P}=0.431 ; \mathrm{P}=$ 0.884 , respectively), suggesting that crown diameter was not well estimated by these explanatory variables. On the other hand, there were significant relationships between DBH and crown diameter, as well as between crown diameter and tree height. Tree height emerged as the stronger predictor of crown diameter for both Terminalia prunioides and Colophospermum mopane. Therefore, the relationship between tree height and crown diameter as explained by cubic function can further be used to evaluate and estimate canopy cover under national park conditions.
\end{abstract}

Key Words: Colophospermum mopane, Combretum imberbe, Namibia, Terminalia prunioides

\section{RÉSUMÉ}

La perte mondiale de biodiversité fait partie des causes des appels incessants des écologistes pour protéger l'environnement et les habitats naturels. L'objectif de cette étude était de déterminer l'efficacité du diamètre du houppier pour prédire la couverture de cime dans les conditions des parcs nationaux. L'étude a été faite dans le parc national d'Etosha, en Namibie en 2015. Trois espèces d'arbres, à savoir Combretum imberbe, Colophospermum mopane et Terminalia prunioides ont été considérées comme des membres représentatifs des espèces du parc en fonction de leur densité de population relative. L'étude a utilisé une analyse de régression pour examiner la nature des relations entre le diamètre du 
houppier (la variable dépendante) et la hauteur de l'arbre, le diamètre à hauteur de poitrine (DBH) et la distance des trous d'arrosage (variables indépendantes). Les coefficients de régression pour Combretum imberbe n'étaient pas significatifs $(\mathrm{P}=0,116 ; \mathrm{P}=0,431 ; \mathrm{P}=0,884$, respectivement), ce qui suggère que le diamètre de la couronne n'était pas bien estimé par ces variables explicatives. D'un autre côté, il y avait des relations significatives entre le DBH et le diamètre de la cime, ainsi qu'entre le diamètre de la cime et la hauteur de l'arbre. La hauteur des arbres est apparue comme le meilleur prédicteur du diamètre du houppier pour Terminalia prunioides et Colophospermum mopane. Par conséquent, la relation entre la hauteur des arbres et le diamètre du houppier, comme expliqué par la fonction cubique, peut en outre être utilisée pour évaluer et estimer le couverture de cime dans les conditions du parc national.

Mots Clés: Colophospermum mopane, Combretum imberbe, Namibie, Terminalia prunioides

\section{INTRODUCTION}

Conservation of wildlife biodiversity from extinction remains a central environmental goal world-over. Conservation and management of national parks are two main efforts that continuously contribute to the survival of wildlife and threatened vegetation species. National Parks offer unique ecologies as they host diverse threatened species of plants and wildlife (Korhonen et al., 2006; Onilude, 2019).

The use of statistical modeling techniques for estimating tree crown cover has significantly become part of the inventory programmes to assess vegetation growth and development (Turpie et al., 2010; Cunning and Jankowitzi, 2011). A tree crown is an aboveground part of a tree that includes the main trunk, the branches that grow out of it, as well as the leaves. It consists of all the parts that are involved in photosynthesis, aerial growth and aboveground reproduction. It is also referred to as tree canopy cover when measured from an aerial standpoint (Gill et al., 2000; Hemery et al., 2005; Korhonen et al., 2006). The tree crown is described as the centre of physiological activities, which largely include the exchange of gases and fluids that drive the development and ultimate growth processes (Buba, 2012). The canopy, therefore, determines how much photosynthesis occurs for each tree within a certain time and place (Hemery et al., 2005; Sharma et al., 2016).
Trees with larger or full crowns have the potential of fixating carbon at a higher rate, and therefore, have a higher amount of net primary production than those with smaller crown sizes (Bechtold et al., 2002). Tree crown sizes are thus used as an ecological indicator of tree growth and health and, consequently, determine various components of the forest ecosystems such as species richness, forest floor microclimate, as well as damage caused by fire in recreation and wildlife habitats (Korhonen et al., 2006; Paletto and Tosi, 2009; Sharma et al., 2016).

Quantification of the crown dimensions is an important component for assessment of tree conditions. This normally includes parameters such as crown cover/crown's size (diameter and/or width or radius), tree height and stem diameter (Bechtold et al., 2002; Hemery et al., 2005; Buba, 2012). Parameters such as tree diameter and height are easy to measure and are also widely used by forest inventory takers (Sánchez-González et al., 2007; Russell and Weiskittel, 2011; Buba, 2012; Sharma et al., 2016). However, not all variables can be easily measured, although their measurements can be good predictors of forest dynamics which can be used to improve the reliability of tools like growth and yield models. Tree crown width is one of the most difficult parameters to measure and is more costly and time consuming than measuring tree diameter at breast height (DBH) and tree height (Avsar, 
2004; Sharma et al., 2016). Moreover, tree crown width, together with $\mathrm{DBH}$, are found to be important characteristics and relevant when correlated with tree growth measurements (Hemery et al., 2005; Sharma et al., 2016); and therefore is used in developing prediction models for crown diameter estimations (Cañadas, 2000; Bragg, 2001; Paulo et al., 2002; Avsar, 2004). Accurate prediction of tree dimensions has become a prominent analytical tool that allows rapid evaluation of wide areas and large volumes of generated data (Turan, 2009; Buba, 2012). The objective of this study was to assess the reliability of crown diameter for prediction of crown cover that can be used in evaluating vegetation growth health, particularly under national park conditions.

\section{MATERIALS AND METHODS}

Study site. This study was conducted in the Etosha National Park, the second largest park in Namibia, with an area of around 22, 270 $\mathrm{Km}^{2}$ (Hipondoka, 2005; Nakanyala, 2012). The Park is mostly flat and has a large proportion (23\%) of saline depression known as the Etosha Pan. The Pan is a vast, bare and open area, which covers around $4800 \mathrm{Km}^{2}$ (Hipondoka, 2005). The Pan is internationally classified as an important wetland, and recognised as a Ramsar site (Cunningham and Jankowitz, 2011). The rainfall gradient in the park ranges from a mean annual of $300 \mathrm{~mm}$ from the west side to $450 \mathrm{~mm}$ to the east (Mendelsohn et al., 2009). Mean annual temperatures range from a minimum of 6.0 ${ }^{\circ} \mathrm{C}$ in winter to a maximum of $34.8{ }^{\circ} \mathrm{C}$ in summer (Beer et al., 2006).

Soils vary from Cambic and Ferralic arenosols sediments to Leptosols and Vertisols in depressions, and Solonchaz and Solonetz soils in the Pan (Beugler-Bell and Buch, 1997; Nakanyala, 2012). The Park consists of a variety of browsers, including elephants which number up to 2000 at times (Berry, 1997; Lindeque and Lindeque, 1997). These browsers often change the structure and composition of the vegetation (Beer et al., 2006). Stander (1991) conveniently divided Etosha National Park into three zones based on Giess' (1971) broad vegetation differences, namely zone one consisting of largely of Colophospermum mopane trees and shrubs interspersed with Terminalia, Vachellia, Senegalia and Sesamothamnus species; zone two comprising mostly Colophospermum trees; and the third zone consisting of Colophospermum mopane, Combretum, Terminalia and Spirostachys africana species. The dominant tree species in Etosha National Park are Colophospermum mopane, Vachellia, Senegalia, Combretum and Terminalia species (Le Roux, 1980; Stander, 1991), with Colophospermum mopane being the most common tree species and estimated to constitute approximately $80 \%$ of all tree species in the Etosha National Park (Berry and Loutit, 2002).

Data collection. The tree species used in this study were Colophospermum mopane, Terminalia prunioides and Combretum imberbe based on their dominance in the study site. These trees were measured from 10 plots established in each site. All together a total of 530 trees were measured. These consisted of 394 Colophospermum mopane, 89 Terminalia prunioides and 47 Combretum imberbe tree species. The selection procedure was purposive, based on tree type and basal circumference. Tree dimensions within $10 \mathrm{~m}$ $\mathrm{x} 10 \mathrm{~m}$ plots were measured. Only trees within $10 \mathrm{~m} \times 10 \mathrm{~m}$ plots with a basal circumference of $16 \mathrm{~cm}$ were measured.

Parameters measured included tree height, crown diameter and stem diameter at breast height. The measurements were done with a measuring tape for stem diameters (the circumference) and a clinometer for the tree height. Crown height was measured by taking the total height and subtracting the distance from the ground level to the base of the live crown (Buba, 2012). Crown diameter was 
308

estimated by taking two diameter measurements at the widest and narrowest sections of the crown at approximately $90^{\circ}$ (Ek, 1974; USDA Forest Service, 2012). The two measurements were then averaged to give mean crown diameter. The DBH was taken at 1.3 meters above ground level.

Data analysis. The Shapiro-Wilk (Shapiro and Wilk, 1965) was used to test for normality of the data. Correlations between outcome variable (crown diameter) and predictor variables (DBH, tree height and distance from watering holes) were computed to determine which predictors were not significantly correlated with the outcome variable (Akinwande et al., 2015). Since the data were not normally distributed, the Spearman correlation analysis (Spearman's rho) was used to compute correlations between crown diameter and $\mathrm{DBH}$; tree height and crown diameter; distance from watering hole and crown diameter. For cases where collinearity was detected, the procedure was to remove one of the collinear variables (Clinebell et al., 1995). Highly correlated predictors supply redundant information and removing one of the correlated factors usually does not drastically reduce the $\mathrm{R}$-squared value (Akinwande et al., 2015). The explanatory variables, which were highly correlated with the dependent variable (crown diameter), were included in the regression. The Curve Estimation procedure from IBM SPSS Statistics version 24 was used to find a bestfit regression model to the data.

A regression equation or model for predicting crown diameter was developed using the Statistical Package for Social Sciences (IBM SPSS Statistics version 24). Linear and non-linear regression equations have been reported in previous studies as adequate for estimating or predicting crown diameter (Korhonen et al., 2006; Akinyemi et al., 2012; Onilude, 2019). Consequently, this study adopted regression analysis, which is one of the tools usually employed to investigate the nature of the association between two or more variables via models (Vanclay, 1994; Harris and Jarvis, 2011).

\section{RESULTS}

Tree height, diameter at breast height and distance. Tree height and diameter at breast height $(\mathrm{DBH})$ were significantly correlated $(\mathrm{r}$ $=0.534, \mathrm{P}<0.001)$ as was crown diameter and tree height (Table 1). The correlation between crown cover and DBH was weak ( $r=0.399$, $\mathrm{P}<0.001)$ when compared with tree height $(r=0.57, P<0.001)$. Tree height emerged the best statistically significant predictor of crown

TABLE 1. Correlation between tree canopy parameters for Terminalia prunioides, Colophospermum mopane and Combretum imberbe $(\mathrm{n}=530)$ found in Etosha National Park in Namibia

\begin{tabular}{lcc}
\hline Parameter & Spearman's rho & P-value \\
\hline Crown diameter - Tree height & 0.571 & $<0.001^{* *}$ \\
Crown diameter - DBH & 0.399 & $<0.001^{* *}$ \\
DBH - Tree height & 0.534 & $<0.001^{* *}$ \\
Crown diameter - Distance & -0.088 & $0.043^{*}$ \\
DBH - Distance & 0.050 & 0.255 \\
Tree height -Distance & -0.015 & 0.728 \\
\hline
\end{tabular}

* Correlation is significant at the 0.05 level (2-tailed test), ${ }^{* *}$ Correlation is significant at the 0.01 level (2-tailed test) 
diameter compared to $\mathrm{DBH}$, while distance from the watering holes was not significant $(\mathrm{P}=0.728)$.

Tree species as a variable. Correlation between crown diameter and tree height showed moderately positive for Terminalia prunioides $(\mathrm{r}=0.5170)$ and Colophospermum mopane $(\mathrm{r}=0.6)$ (Table 2). The correlation between crown diameter and tree height showed a very weak relationship $(\mathrm{r}=0.4)$ for Combretum imberbe. Furthermore, tree height, DBH and distance could not significantly predict crown diameter for Combretum imberbe (Table 3).

The relationships between DBH and crown diameter, as well as between crown diameter and tree height were significant for both
Terminalia prunioides and Colophospermum mopane.

Of the three predictor variables, tree height showed the highest explanatory power, $\mathrm{R}^{2}=$ 0.477 and 0.40 for Terminalia prunioides and Colophospermum mopane, respectively. This explains about $48 \%$ of the variation in crown diameter among Terminalia prunioides trees and $40 \%$ of the crown diameter variation for Colophospermum mopane. Diameter at breast height explained about $7 \%\left(\mathrm{R}^{2}=0.071\right)$ for Terminalia prunioides and $15 \%\left(\mathrm{R}^{2}=0.154\right)$ for Colophospermum mopane. All these relationships were highly significant $(\mathrm{P}<0.05)$. Tree height emerged the best statistically significant predictor of crown diameter and was used alone in the prediction model for crown diameter. Relationships between crown

TABLE 2. Correlation of tree crown diameter and height per species in Etosha National Park in Namibia

\begin{tabular}{lcc}
\hline Species & Correlation coefficient & P-value \\
\hline Terminalia prunioides & 0.517 & $<0.000^{* *}$ \\
Colophospermum mopane & 0.600 & $<0.000^{* *}$ \\
Combretum imberbe & 0.407 & $0.005^{* *}$ \\
\hline
\end{tabular}

*Relationship is significant at the 0.05 level (2-tailed test), **Relationship is significant at the 0.01 level (2-tailed test)

TABLE 3. Relationships between tree crown diameter and different parameters for different species found in Etosha National Park in Namibia

\begin{tabular}{llc}
\hline Parameter & Tree species & P-value \\
\hline Tree height & Colophospermum mopane & $<0.01^{*}$ \\
Tree height & Terminalia prunioides & $<0.01^{*}$ \\
Tree height & Combretum imberbe & 0.116 \\
DBH & Colophospermum mopane & $<0.01^{*}$ \\
DBH & Terminalia prunioides & $0.011^{*}$ \\
DBH & Combretum imberbe & 0.431 \\
Distance & Colophospermum mopane & 0.213 \\
Distance & Terminalia prunioides & 0.253 \\
Distance & Combretum imberbe & 0.884
\end{tabular}

*. Relationship is significant at the 0.05 level (2-tailed test) 


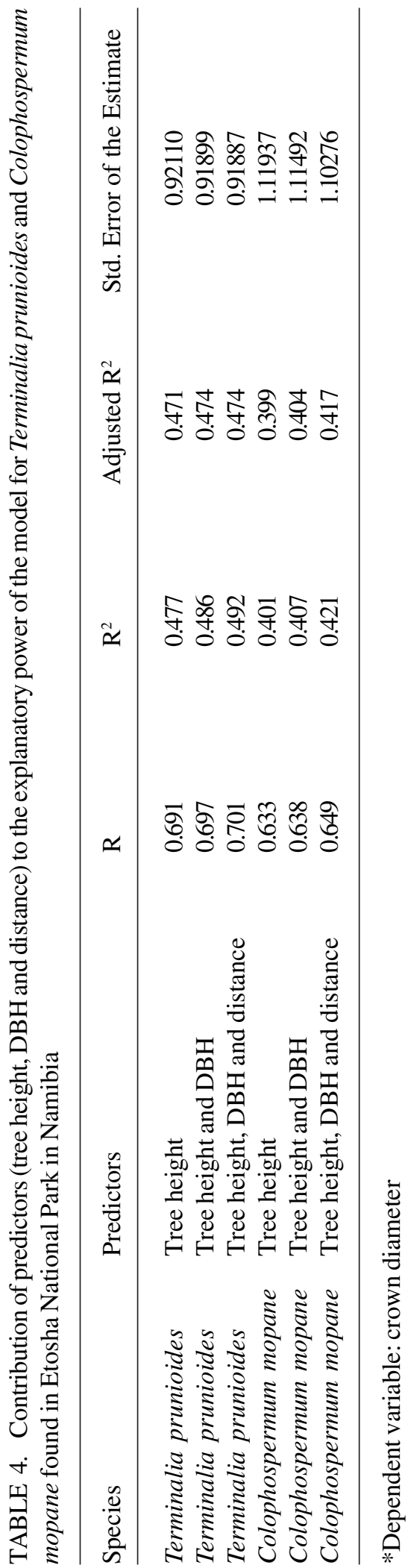

S.T. ANGOMBE et al.

diameter and distance were not significant for Colophospermum mopane $(\mathrm{P}=0.213)$ and Terminalia prunioides $(\mathrm{P}=0.253)$.

Curve estimation. Crown diameter was analysed with tree height as the independent variable And up to 10 regression model models were investigated for predictive value of crown diameter for Terminalia prunioides, Colophospermum mopane and Combretum imberbe (Tables 5-7).

The cubic regression models fitted the data best with a coefficient of determination of approximately 56 and $40.4 \%$ for Terminalia prunioides and Colophospermum mopane, respectively (Tables 5 and 6).

$\mathrm{Y}=\mathrm{a}+\mathrm{b}_{1} \mathrm{X}+\mathrm{b}_{2} \mathrm{x}^{2}+\mathrm{b}_{3} \mathrm{x}^{3} \ldots \ldots \ldots \ldots$ Equation 1

Where:

$\mathrm{Y}=$ crown diameter $\mathrm{a}=\operatorname{constant}(\mathrm{Y}$ intercept $)$, $b_{k}=$ coefficient of the independent variable to the $\mathrm{k}^{\text {th }}$ power.

\section{Crown prediction model for Terminalia} prunioides. Regression analysis results showed significant $(\mathrm{P}<0.05)$ and strong $\left(\mathrm{R}^{2}<\right.$ $0.50)$ relationships between tree height and crown diameter variables for this model (Fig. 1). The tree height-crown diameter relationship was best described by the cubic model $\left(R^{2}=0.56\right)$.

Validating the model. The correlation between outcome variable (the actual crown diameter) and the predicted value of crown diameter, according to the crown prediction model for Terminalia prunioides was 0.7 (Fig. 2 ), which indicated a strong positive correlation. The predicted values of crown width plotted on the observed values are additional evidence of the model adequacy for prediction of crown cover (Fig. 2).

Crown diameter prediction model for Colophospermum mopane. Regression analysis results showed a significant $(\mathrm{P}<0.05)$ 
TABLE 5. Model statistics and parameters estimates of the prediction model for Terminalia prunioides

\begin{tabular}{|c|c|c|c|c|c|c|c|c|c|}
\hline \multirow[t]{2}{*}{ Equation } & \multicolumn{5}{|c|}{ Model summary } & \multicolumn{4}{|c|}{ Parameter estimates } \\
\hline & $\mathrm{R}^{2}$ & $\mathrm{~F}$ & df1 & $\mathrm{df} 2$ & Sig. & Constant & b1 & b2 & b3 \\
\hline Linear & 0.48 & 79.486 & 1 & 87 & 0.000 & 1.192 & 0.702 & & \\
\hline Logarithmic & 0.41 & 60.241 & 1 & 87 & 0.000 & .333 & 2.737 & & \\
\hline Inverse & 0.33 & 42.448 & 1 & 87 & 0.000 & 6.518 & -9.143 & & \\
\hline Quadratic & 0.53 & 49.062 & 2 & 86 & 0.000 & 4.088 & -.660 & 0.147 & \\
\hline Cubic & 0.56 & 36.186 & 3 & 85 & 0.000 & -2.691 & 4.464 & -1.051 & 0.087 \\
\hline Compound & 0.40 & 57.967 & 1 & 87 & 0.000 & 1.977 & 1.179 & & \\
\hline Power & 0.37 & 51.826 & 1 & 87 & 0.000 & 1.555 & 0.669 & & \\
\hline Growth & 0.40 & 57.967 & 1 & 87 & 0.000 & .682 & 0.164 & & \\
\hline Exponential & .400 & 57.967 & 1 & 87 & 0.000 & 1.977 & 0.164 & & \\
\hline Logistic & .400 & 57.967 & 1 & 87 & 0.000 & .506 & 0.848 & & \\
\hline
\end{tabular}

TABLE 6. Model statistics and parameters estimates of the prediction model for Colophospermum mopane

\begin{tabular}{|c|c|c|c|c|c|c|c|c|c|}
\hline \multirow[t]{2}{*}{ Equation } & \multicolumn{5}{|c|}{ Model summary } & \multicolumn{4}{|c|}{ Parameter estimates } \\
\hline & $\mathrm{R}^{2}$ & $\mathrm{~F}$ & df1 & $\mathrm{df} 2$ & Sig. & Constant & b1 & $\mathrm{b} 2$ & b3 \\
\hline Linear & 0.401 & 262.223 & 1 & 392 & 0.000 & 1.858 & 0.476 & & \\
\hline Logarithmic & 0.395 & 256.444 & 1 & 392 & 0.000 & .323 & 2.532 & & \\
\hline Inverse & 0.354 & 214.389 & 1 & 392 & 0.000 & 6.728 & -10.960 & & \\
\hline Quadratic & 0.403 & 132.207 & 2 & 391 & 0.000 & 1.341 & 0.671 & -0.016 & \\
\hline Cubic & 0.404 & 88.164 & 3 & 390 & 0.000 & 2.018 & 0.283 & 0.051 & -0.004 \\
\hline Compound & 0.362 & 222.175 & 1 & 392 & 0.000 & 2.344 & 1.113 & & \\
\hline Power & 0.381 & 241.554 & 1 & 392 & 0.000 & 1.609 & 0.590 & & \\
\hline Growth & 0.362 & 222.175 & 1 & 392 & 0.000 & 0.852 & 0.107 & & \\
\hline Exponential & 0.362 & 222.175 & 1 & 392 & 0.000 & 2.344 & 0.107 & & \\
\hline Logistic & 0.362 & 222.175 & 1 & 392 & 0.000 & 0.427 & 0.898 & & \\
\hline
\end{tabular}

TABLE 7. Crown diameter prediction coefficients with tree height as the independent variable based on the cubic regression model

\begin{tabular}{lrrrrrr}
\hline Species & $\mathrm{N}$ & $\mathrm{b}_{0}$ & $\mathrm{~b}_{1}$ & $\mathrm{~b}_{2}$ & $\mathrm{~b}_{3}$ & $\mathrm{R}^{2}$ \\
\hline Terminalia prunioides & 89 & -2.691 & 4.464 & -1.051 & 0.087 & 0.56 \\
Colophospermum mopane & 394 & 2.0181 & 0.2835 & 0.0509 & -0.0035 & 0.40 \\
Combretum imberbe & 47 & -1.5619 & 2.6423 & -0.3752 & 0.0168 & 0.13 \\
\hline
\end{tabular}




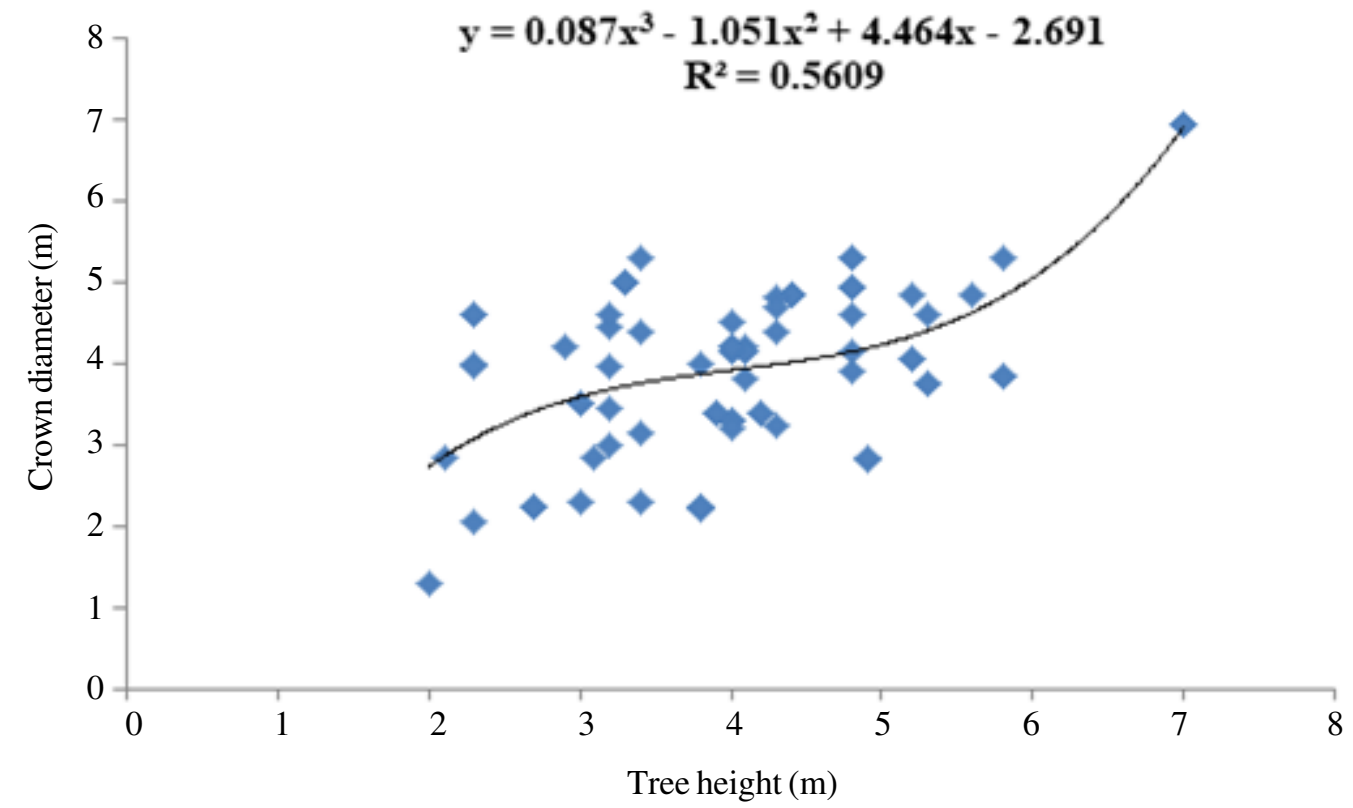

Figure 1. Cubic regression model for Terminalia prunioides in terms of tree height and crown diameter in the Etosha National Park in Namibia.

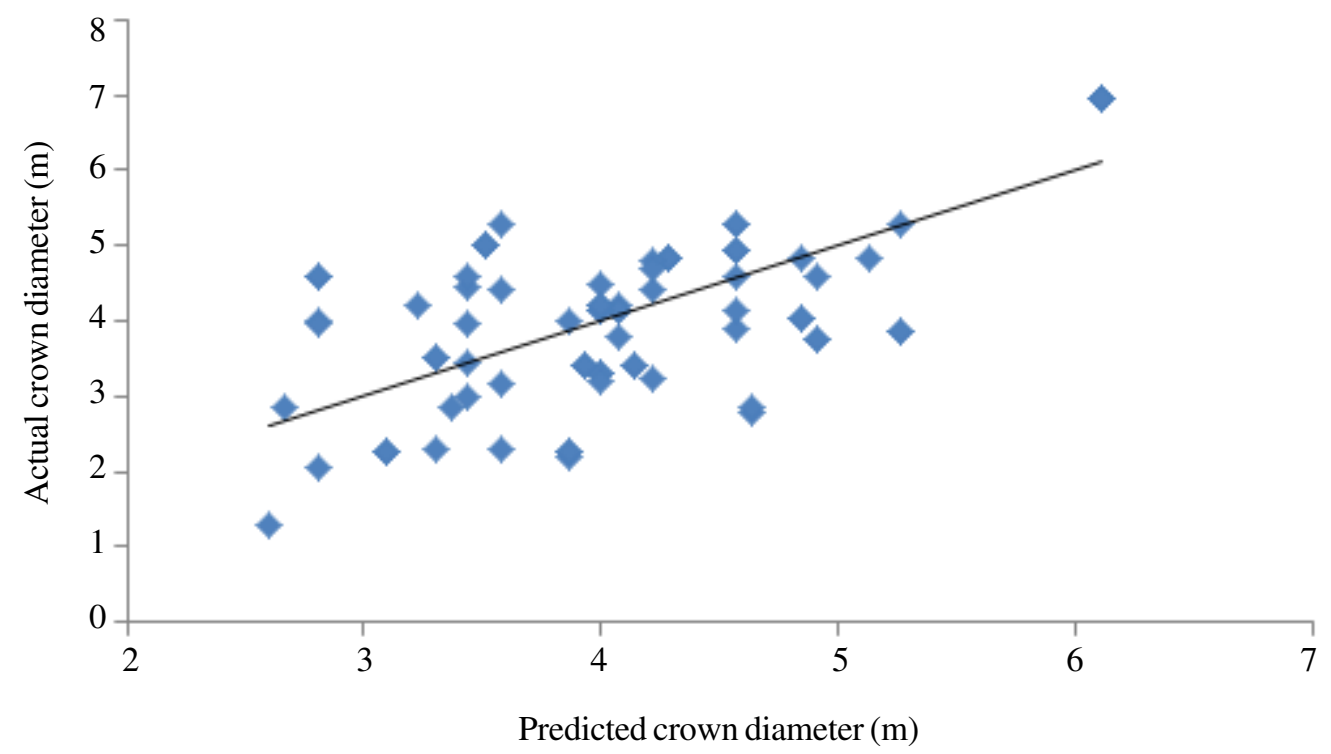

Figure 2. The predicted values of tree crown diameter plotted on the observed values for Terminalia prunioides in Etosha National Park in Namibia. 


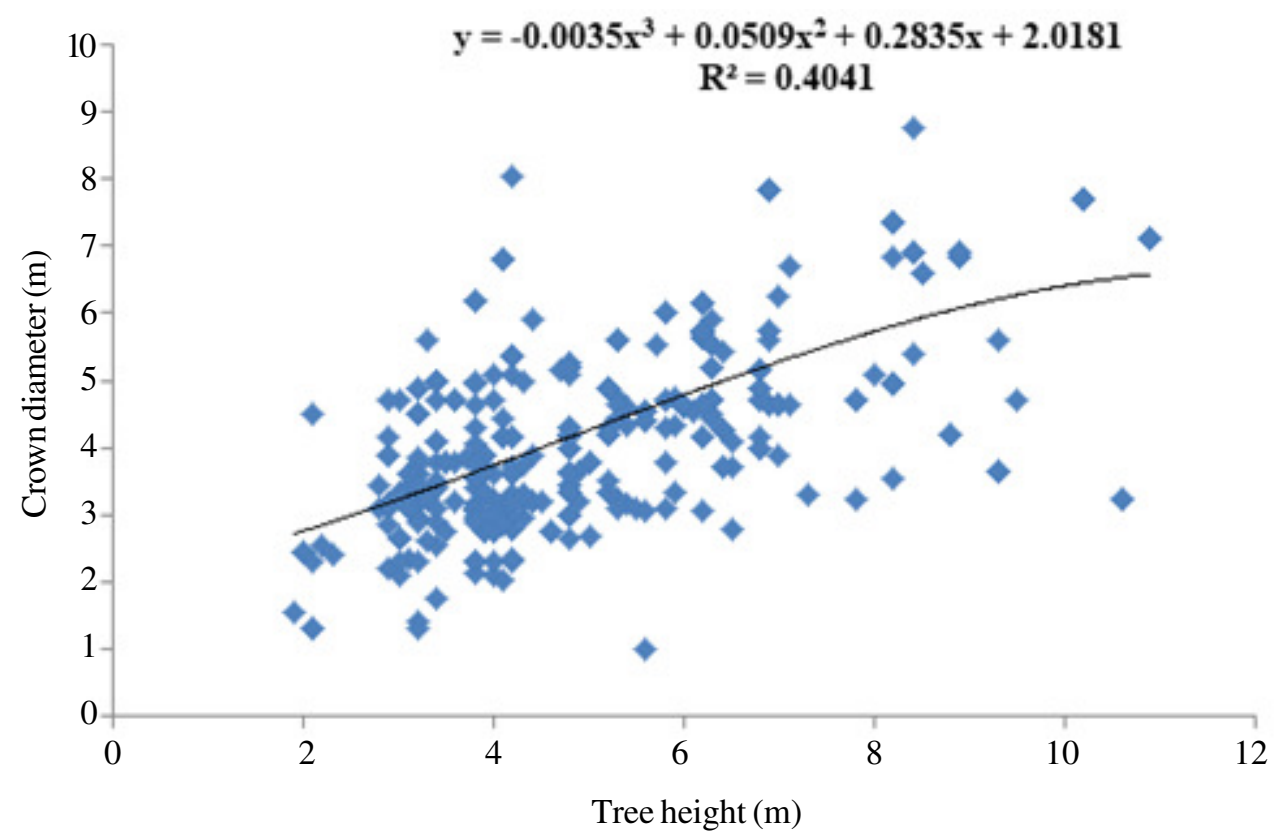

Figure 3. Cubic regression model for Colophospermum mopane in terms of tree height and crown diameter for trees in Etosha National Park in Namibia.

and strong $\left(\mathrm{R}^{2}>0.50\right)$ relationship between tree height and crown diameter variables for this model (Fig. 3). The tree height-crown diameter relationship was best described by the cubic model $\left(\mathrm{R}^{2}=0.40\right)$.

Validating the model. The correlation between the outcome variable (the actual crown diameter) and the predicted values of crown diameter for Colophospermum mopane was 0.63 , which also indicated a strong positive correlation. The predicted values of crown width plotted on the observed values are additional evidence of the model adequacy for prediction of crown cover (Fig. 4).

\section{DISCUSSION}

The results of this study have revealed that the cubic model gives the best performance for fitting crown prediction models (Tables 5 and 6). The cubic model gave the best performance according to the regression estimates used, compared to the models in the fitting phase. Consequently, this model was selected. Although previous studies have shown that the cubic regression model is the best for fitting data when predicting crown diameter (Akinyemi et al., 2012), few studies have demonstrated the usefulness of tree height as a predictor (Avsar, 2004; SánchezGonzález et al., 2007). The correlation between crown diameter and DBH was weak $(\mathrm{r}=0.399)$ when compared with tree height $(r=0.57)$, which may suggest that great variation of crown width exists using this predictor.

In most cases DBH has been reported as the best estimator of crown diameter (Cañadas, 2000; Paulo et al., 2002; Akinyemi et al., 2012). On the contrary, this study revealed a significant, moderately strong and positive nonlinear relationship between crown diameter and tree height (Fig. 1). DBH and tree height were correlated (Table 1), thus were collinear. Collinearity violates the assumption of independence of explanatory variables (all explanatory variables must be independent of each other; only the outcome variable may be dependent on the predictors or the explanatory 


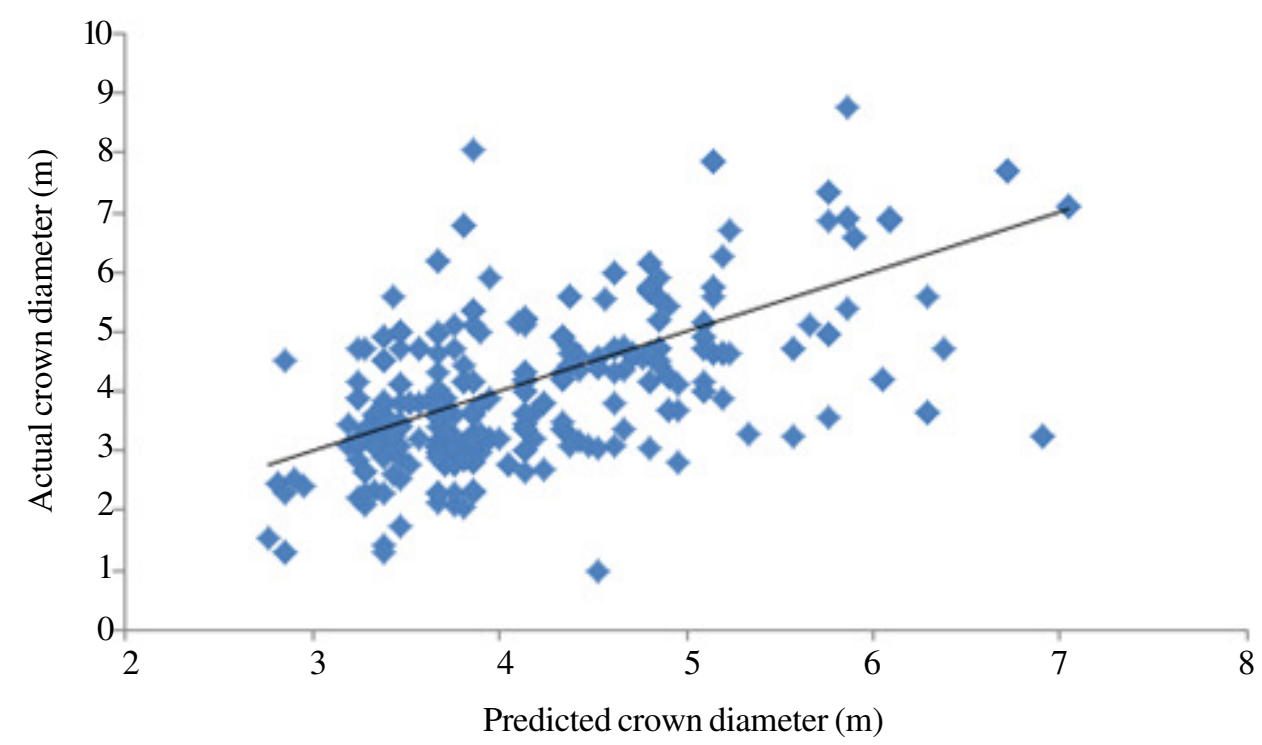

Figure 4. The predicted values of tree crown diameter plotted on the observed values for Colophospermum mopane in Etosha National Park in Namibia

variables, not the other way around) and thus adversely affects regression estimates (coefficients and standard errors).

Overall the crown diameter models for Colophospermum mopane and Terminalia prunioides species presented here explained between $\sim 40 \%$ and $\sim 56 \%$ of the variation seen in crown diameter, respectively. The model for Colophospermum mopane explained only about $40 \%$ of the observed variability. Various reasons can be advanced for the unexplained variation. These may include the grazing and browsing patterns of wild animals, especially large herbivores; the extent of their impacts on the dynamics of the vegetation species; and the inter-relationships among soils, vegetation and wild animals. However, no data on elephant damage patterns were collected for the study.

The model for Terminalia prunioides appears to be a more reliable one in terms of coefficient significance and variation explained by the model (Fig. 2). Akinyemi et al. (2012) established a significant relationship between $\mathrm{DBH}$ and crown diameter and reported that DBH adequately predicts crown diameter.
However, this study has identified tree height as a better crown diameter predictor. This difference could be attributed to differences in site conditions between the two study areas. Though both trees belong to the Combretaceae family, Terminalia superba is a large tree in the family native to tropical western Africa and grows up to $60 \mathrm{~m}$ tall; whereas Terminalia prunioides is a shrub or tree found in the savannah biome and only grows up to $8 \mathrm{~m}$ (Le Roux et al., 2009).

The Combretum imberbe species model had less total variation explained and the regression coefficients were not statistically significant, indicating that their values were not well estimated. The low $\mathrm{R}^{2}(0.1333)$ value for Combretum imberbe may indicate a high degree of morphological variation. This suggests that variation of crown diameter for Combretum imberbe which may require additional parameters to enable the creation of reasonable prediction equations. When creating these models, it may be beneficial to account for the potential added variation in stem and crown form. 


\section{CONCLUSION}

Although crown diameter prediction models are simplified representations of this complex parameter, well-constructed models should be viewed as reasonable estimates capable of aiding the national park management in assessing vegetation health. The results of this study clearly demonstrate that crown diameter can be estimated by means of tree height, which is easy to measure. Therefore, the tree height-crown diameter relationship should be used for the estimation of crown cover. The tree height-crown diameter relationship can be best described by the cubic regression model in less disturbed areas like the Etosha National Park.

\section{ACKNOWLEDGEMENT}

The authors would like to thank the University of Namibia, for providing funding to conduct fieldwork. Appreciation is as well extended to personnel of the Etosha Ecological Institute of the Ministry of Environment and Tourism for assistance with logistics and equipment to complete the fieldwork as well as for providing us with necessary additional data. The authors are grateful to the Mastercard Foundation and Regional Universities Forum for Capacity Building in Agriculture (RUFORUM) for funding publication cost through the Transforming African Agricultural Universities to meaningfully contribute to Africa's growth and development (TAGDev) Program.

\section{REFERENCES}

Akinyemi, G.O., Ige, P.O. and Smith, A.S. 2012. Evaluation crown-diameter prediction models for Terminalia superb (Engl. \& Diels) in Onigambari Forest Reserve, Nigeria. Journal of Forestry Research and Management 9: 37-44.

Akinwande, M.O., Dikko, H.G. and Samson, A. 2015. Variance inflation factor: As a condition for the inclusion of suppressor variable(s) in regression analysis. Open Journal of Statistics 5(7):754-767. http:// dx.doi.org/10.4236/ojs.2015.57075.

Avsar, M.D. 2004. The relationships between diameter at breast height, tree height and crown diameter in Calabrian pines (Pinus brutia Ten.) of Baskonus Mountain, Kahramanmaras, Turkey. Journal of Biological Sciences 4(4):437-440.

Bechtold, W.A., Mielke, M.E. and Zarnoch, S.J. 2002. Comparison of field methods and models to estimate mean crown diameter. Northern Journal of Applied Forestry 19(4):177-182.

Beer, Y., Kilian, W., Versfeld, W. and Van Aarde, R. J. 2006. Elephants and low rainfall alter woody vegetation in Etosha National Park, Namibia. Journal of Arid Environments 64(3):412-421.

Berry, H.H. 1997. Historical review of the Etosha Region and its subsequent administration as a National Park. Madoqua 20(1):3-12.

Berry, C. and Loutit, B. 2002. Trees and shrubs of the Etosha National Park and in northern and central Namibia. Namibia Scientific Society. Windhoek, Namibia.

Beugler-Bell, H. and Buch, M.W. 1997. Soil and soil erosion in the Etosha National Park, Northern Namibia. Madoqua 20(1):91-104.

Bragg, D.C. 2001. A local basal area adjustment for crown width prediction. Northern Journal of Applied Forestry 18(1):22-28.

Buba, T. 2012. Prediction equations for estimating tree height, crown diameter, crown height and crown ratio of Parkia Biglobosa in the Nigerian Guinea Savanna. African Journal of Agricultural Research 7(49):6541-6543.

Cañadas, N. 2000. Pinus pinea L. en el Sistema Central (Valle del Tiétar y del Alberche): desarrollo de un modelo de crecimiento y producción de piña (Doctoral dissertation, Ph.D. Thesis, ETSI de Montes, Universidad Politécnica de Madrid). 
Clinebell, R.R., Phillips, O.L. Gentry, A.H. Stark, N. and Zuring, H. 1995. Prediction of neo-tropical tree and liana species richness from soil and climatic data. Biodiversity and Conservation 4:56-90.

Cunningham, P.L. and Jankowitz, W. 2011. A review of fauna and flora associated with coastal and inland Saline flats from Namibia with Special Reference to the Etosha Pan. Task for Vegetation Studies 46(34):9-17.

Ek, A.R. 1974. Dimensional relationship of forest and open grown trees in Wisconsin. Forest Research Note 181. University of Wisconsin, School of Natural Resources. Madison, Wisconsin, USA.

Giess, W. 1971. A preliminary vegetation map of South West Africa. Dinteria 4:1-114.

Gill, S.J., Biging, G.S. and Murphy, E.C. 2000. Modeling conifer tree crown radius and estimating canopy cover. Forest Ecology and Management 126(3):405-416.

Harris, R. and Jarvis, C. 2011. Statistics for geography and environmental science. Pearson Education Limited, Harlow, England.

Hemery, G.E., Savill, P.S. and Pryor, S.N. 2005. Applications of the crown diameterstem diameter relationship for different species of broadleaved trees. Forest Ecology and Management 215(1-3):285294.

Hipondoka, M.H. 2005. The development and evolution of Etosha pan. Namibia (Doctoral thesis), Julius-Maximilians-Universität, Würzburg, Germany.

Korhonen, L., Korhonen, K.T., Rautiainen, M. and Stenberg, P. 2006. Estimation of forest canopy cover: a comparison of field measurement techniques. Silva Fennica 40(4):577- 588.

Lindeque, M. and Lindeque, P. M. 1997. Aerial sample counts of large game in northern Namibia. Madoqua 19(2):75-86.

Le Roux, C.J.G. 1980. Vegetation classification and related studies in the Etosha National Park. Ph.D. Thesis. University of Pretoria, South Africa.
Le Roux, P., Müller, M., Mannheimer, C.A. and Curtis, B. 2009. Le Roux and Müller's Field Guide to the Trees and Shrubs of Namibia. Windhoek, Namibia: MacMillan Education.

Mendelsohn, J., Jarvis, A., Roberts, C. and Robertson, T. 2009. Atlas of Namibia: A portrait of the land and its people. Sunshine Publishers. Cape Town, South Africa.

Nakanyala, J. 2012. Impact of tourism on the landscape and vegetation along tourist roads in Etosha National Park, Namibia. (Masters Thesis), University of Namibia, Windhoek Namibia.

Onilude, Q.A. 2019. Development and evaluation of linear and non-linear models for diameter at breast height and crown diameter of TriplochitonScleroxylon (K. Schum) Plantations in Oyo State, Nigeria. Journal of Agriculture and Veterinary Science 12(6):47-52.

Paletto, A. and Tosi, V. 2009. Forest canopy cover and canopy closure: comparison of assessment techniques. European Journal of Forest Research 128(3):265-272.

Paulo, M.J., Stein, A. and Tomé, M. 2002. A spatial statistical analysis of cork oak competition in two Portuguese silvopastoral systems. Canadian Journal of Forest Research 32(11):1893-1903.

Russell, M.B. and Weiskittel, A.R. 2011. Maximum and largest crown width equations for 15 tree species in Maine. Northern Journal of Applied Forestry 28(2):84-91.

Sánchez-González, M., Cañellas, I. and Montero, G. 2007. Generalized heightdiameter and crown diameter prediction models for cork oak forests in Spain.Forest Systems 16(1):76-88.

Shapiro, S.S. and Wilk, M.B. 1965. An analysis of variance test for normality. Biometrika 52:591-611.

Sharma, R.P., Vacek, Z. and Vacek, S. 2016. Individual tree crown width models for Norway spruce and European beech in 
Czech Republic. Forest Ecology and Management 366:208-220.

Stander, P.E. 1991. Demography of lions in the Etosha National Park. Madoqua 18(1): 1-9.

Turan, S. 2009. Diameter at breast height crown diameter prediction models for Piceaorientalis. African Journal of Agricultural Research 4(3):215-217.

Turpie, J., Barnes, J., Lange, G.M. and Mart, R. 2010. The Economic value of Namibia's
Protected Areas. Windhoek Namibia: Ministry of Environment and Tourism. USDA Forest Service. 2012, October. Forest inventory and analysis national core field guide. National Core Field Guide, Version 6.0. United States Department Agriculture Forest Service. USA.

Vanclay, J.K. 1994. Modelling forest growth and yield: applications to mixed tropical forests. School of Environmental Science and Management Papers 537. 